\title{
PENINGKATAN MUTU PENDIDIKAN MENGGUNAKAN \\ SUPERVISI UNTUK MENCAPAI PENDIDIKAN \\ YANG BERKUALITAS DI ERA MODERN
}

\author{
Mirna indah safitri \\ Mirnaindahsafitri07@gmail.com
}

\begin{abstract}
ABSTRAK
Pendidikan yang bermutu akan meningkatkan keberhasilan dari suatu sekolah. Untuk mencapai keberhasilan tersebut dilakukan usaha yang dapat menunjang tercapainya keberhasilan. Peningkatan mutu pendidikan dengan supervisi dapat dilakukan dengan cara meningkatkan kualitas dari guru. Diharapkan guru dapat menjadi pelaksana peningkatan mutu pendidikan yang sudah memiliki teknologi informasi yang canggih pada era modern saat ini.
\end{abstract}

Kata kunci: Supervisi pendidikan, era modern, mutu pendidikan

\section{LATAR BELAKANG}

Saat ini kemampuan mengajar memerlukan seperangkat pengetahuan dan keterampilan tertentu, agar dapat melaksanakan tugasnya dengan semestimya. Kemampuan mengajar mulai dibentuk sejak para mahasiswa calon guru mengikuti perkuliahan pada lembaga pendidikan guru. Selanjutnya keterampilan mengajar dapat dikembangkan atau ditingkatkan melalui pembinaan dalam jabatan di lapangan, hal ini dapat dilakukan dengan usaha mandiri maupun dengan bantuan orang lain. Kegiatan supervisi pendidikan memiliki tujuan, sasaran dan esensi yang lebih bernuansa pembinaan dalam rangka membantu meningkatkan kegiatan proses belajar mengajar guru di kelasnya, dan dilaksanakan secara terprogram. Kemajuan teknologi informasi saat ini mendesak guru untuk lebih paham dengan teknologi informasi tersebut.

Berdasarkan uraian diatas, permasalahan dalam tulisan ini adalah (1) Bagaimana pelaksanaan supervisi pendidikan di sekolah? (2) Bagaimana cara untuk meningkatkan kualitas pendidikan di era modern saat ini? Tujuan dari tulisan ini adalah bagaimana cara untuk meningkatkan kualitas pendidikan di era modern. 
Pada hakekatnya supervisi pendidikan memiliki esensi yang bernuansa pembimbingan terhadap proses belajar mengajar guru. Seharusnya supervisi dilakukan dalam rangka menjamin pembelajaran yang berkualitas. Sehingga menghasilkan peserta didik yang dapat bersaing di dunia luar. Strategi yang digunakan haruslah sistematis, terarah, dan berkesinambungan yang diharapkan dapat mewujudkan kualitas pendidikan yang meningkat. Supervisi pendidikan akan berjalan dengan lancar jika mereka yang diharapkan dapat melaksanakan tugasnya dengan baik dan teratur. Pendidikan yang bermutu adalah impian semua kalangan. Dalam supervisi pendidikan diperlukannya manajemen mutu pendidikan yang dapat meningkatkan kualitas pendidikan di sekolah. Peningkatan kualitas sarana dan prasarana juga diperlukan seperti halnya teknologi dan informasi yang dapat menunjang kinerja guru dan peserta didik agar tidak ketinggalan zaman.

Sebagaimana dikemukakan oleh Sabandi (Sabandi, 2013) Perkembangan ilmu pengetahuan, teknologi, dan sosial ekonomi masyarakat dapat lebih memperluas variasi pendekatan peningkatan kapasitas guru. Secara umum dikenal, supervisi dilakukan oleh supervisor dengan melakukan kunjungan kelas. Supervisor memeriksa persiapan guru mengajar dan mengomentari persiapan mengajar yang dibuat oleh guru. Selanjut mengamati mengajar dan mencatat segala sesuatu berkenaan dengan pelaksanaan pembelajaran yang dilakukan oleh guru. Hasil pengamatan tersebut dibicarakan dengan guru; supervisor memberikan komentar kepada guru tentang hal-hal yang perlu ditingkatkan. Pendekatan supervisi yang demikian tidak selalu dilakukan secara utuh. Sering supervisi dilakukan hanya sampai pada tahap memeriksa rencana pembelajaran atau mengamati pelaksanaan pembelajaran guru di kelas.

Pembinaan terhadap guru yang dikemukakan oleh Kadarwati (Kadarwati, 2016) merupakan kegiatan penting dalam upaya peningkatan kualitas pendidikan pada umumnya dan secara khusus untuk peningkatan kualitas pembelajaran. Kepala Sekolah sebagai memiliki tugas membina dan membimbing para guru terutama membina dan menumbuhkan profesionalitas guru.

Ilmu pengetahuan dan teknologi semakin berkembang pesat demikian pula dengan masyarakatnya. Teknologi mempengaruhi pengajaran, nilai-nilai, ilmu pengetahuan yang dimiliki peserta didik kian meningkat. Untuk menghadapi semua itu guru harus memahami berbagai masalah dan akibat dari perkembangan tersebut. Maka dari itu sudah seharusnya guru meningkatkan wawasan dan pengetahuan yang akan menjadi pondasi dan landasan untuk mengajar di dalam kelas kepada peserta didik.

\section{PENUTUP}

\section{Kesimpulan}

Berdasarkan pembahasan diatas disimpulkan bahwa supervisi pendidikan merupakan bentuk pembinaan dalam peningkatan mutu pembelajaran yang dilakukan oleh guru agar dapat menuju ke arah yang lebih baik.Mutu pendidikan di sekolah dapat diartikan sebagai kemampuan sekolah dalam mengelola secara operasional dan efisien terhadap komponen-komponen yang berkaitan dengan sekolah, sehingga menghasilkan 
nilai tambah terhadap komponen-komponen menurut norma atau standar yang berlaku. Untuk meningkatkan mutu pendidikan Guru juga harus mengetahui bahwa pada era modern saat ini teknologi informasi sudah berkembang pesat sehingga guru pun harus

dibimbing untuk lebih meningkatkan kualitas pengetahuan di bidang teknologi dan informasi.

\section{Saran}

Dalam upaya meningkatkan kualitas pendidikan dalam belajar mengajar guru perlu memantapkan lagi cara pengelolaan supervisi pendidikan dan pengelolaan mutu pendidikan agar tidak tertinggal dari sekolah yang lain.

\section{REFERENSI}

Kadarwati, A. (2016). Peningkatan Kualitas Pembelajaran Melalui Supervisi Akademik Dengan Teknik Kunjungan Kelas. Studi Sosial, 1(2), 1-18. Retrieved from https://www.google.com/search?safe=strict\&ei=9n29XKjaEaXZz7sP84qk8AY\&q=j urnal+supervisi+pendidikan+ani+kadarwati+pdf\&oq=JURNal+supervisi+pendidikan +ani+kadarwati\&gs_l=psyab.1.0.33i160.5081.10222..12912...0.0..0.826.3626.0j5j4j1j2j0j1......0....1..gwswiz.......35i39j0i22i30j33i22i29i30.Bsuxx2Ff54E

Sabandi, A. (2013). Supervisi Pendidikan Untuk Pengembangan Profesionalitas Guru Berkelanjutan. Pedagogi, XIII(2), 1-9. Retrieved from http://ejournal.unp.ac.id/index.php/pedagogi/article/view/4275/3345 